\author{
Інна Осадченко, \\ доктор педагогічних наук, професор, \\ професор кафедри педагогіки \\ та освітнього менеджменту, \\ Уманський державний педагогічний \\ університет імені Павла Тичини \\ (м. Умань, Україна)
}

\section{Inna Osadchenko,}

doctor of pedagogical sciences, professor, professor departments of pedagogy

and educational management, Uman state pedagogical university named Pavlo Tychyna (Uman, Ukraine) osadchenkoinna1@gmail.com ORCID ID 0000-0003-0682-5145

\section{Руслан Маслюк,}

кандидат педагогічних наук, доцент, завідувач кафедри спортивних дисциплін, Уманський державний педагогічний університет імені Павла Тичини (м. Умань, Україна)

\section{Ruslan Masliuk,}

$\mathrm{PhD}$ in Education, associate professor, head of Sport Subjects Department, Uman state pedagogical university named Pavlo Tychyna (Uman, Ukraine)

\title{
СУТНІСТЬ ТА ДИСКУСІЙНІ ПИТАННЯ ПРОБЛЕМИ АКАДЕМІЧНОЇ ДОБРОЧЕСНОСТІ
}

Анотація. У статті на основі аналізу наукових джерел та емпіричного матеріалу з'ясовано сучасну сутність поняття «академічна доброчесність / недоброчесність» та схарактеризовано дискусійні питання кола досліджуваної проблеми. Уточнено назву окремих видів плагіату зі вказівкою на практичні приклади та шляхи усунення таких помилок: прямий плагіат, набір цитат, цитування за цитуванням, неправильний переклад. Доведено, що до плагіату найменше вдаються ті здобувачі освіти та науковці, у котрих вимогливі викладачі ще на етапі перших років студентства не допускали порушення ними норм академічної доброчесності. Запропоновано з першого курсу університету навчати здобувачів освіти основам наукової етики та технологіям виконання наукових робіт. Узагальнено пропозиції дослідників щодо шляхів усунення академічної недоброчесності. Визначено психологічні причини порушення академічної доброчесності: заздрість стосовно наукових досягнень інших колег; страх перед невиконанням наукового завдання; комплекси неповноцінності, невпевненості та зневіри у своїх силах; лінь та використання легких шляхів виконання роботи; соціальна «мода» на поведінку за зразком пошуку легкого виконання будь-якої роботи тощо. Визначено дискусійні питання контексту самоплагіату як несвідомого порушення академічної доброчесності шляхом оприлюднення результатів дисертаційних робіт у перефразованих статтях тощо. Описано сутність прямої «академічної крадіжки», тобто оприлюднення чужих ідей до моменту їх публікації самим автором. Визначено методи убезпечення від прямої «академічної крадіжки» шляхом дотримання «дослідницько-авторської безпеки». Схарактеризовано методи уникнення окремих видів плагіату шляхом створення єдиної електронної бази даних щодо затвердження ученими радами закладів вищої освіти та наукових інститутів тем наукових досліджень з метою відстеження тенденцій сучасних науковопедагогічних досліджень та убезпечення їх дублювання. Вказано на значущість нормативно-правового забезпечення та 
дієвість механізмів покарання за вияв академічної недоброчесності. Наголошено на убезпеченні від несправедливого покарання шляхом кількаступеневої перевірки вірогідності наукового порушення тощо.

Ключові слова: академічна доброчесність, академічна недоброчесність, плагіат, види плагіату, правильність цитування, самоплагіат.

\section{BASIC NATURE AND DEBATABLE ISSUES OF ACADEMIC VIRTUE}

Abstract. Preceeding from scientific research publications and empiric material the article demonstrates current nature of the term 'academic virtue/dishonesty' and describes debatable issues of the studied problem. The names of several types of plagiarism have been specified; the following practical examples and elimination methods of the mistakes have been provided: direct plagiarism, quotation set, citation by citation, incorrect translation. The article proves that they are the education applicants and researchers who use plagiarism, because during their first years of studying the demanding professors didn't tolerate their academic virtue norms violation. The author recommends education applicants teaching of the fundamentals of academic ethics and the technologies of scientific works performance. The researchers' recommendations on the elimination methods of academic dishonesty have been summarized. Psychological reasons for academic virtue violation have also been described: envy of their colleagues scientific achievements; fear of scientific task nonfulfillment; inferiority complex, complexes of diffidence and discouragement; laziness and using of easy ways for work performance; social 'fashion' for the behavior like easy performance of any work, etc. The article shows debatable issues of self-plagiarism context as academic virtue unconscious violation via publishing of thesis results in paraphrased articles, etc. The basic nature of direct 'academic theft' - publishing of other's ideas up to the moment of their publishing by the author - has been identified. Securing methods against direct 'academic theft' via following 'research and authorial secure' have been specified. Elimination methods against specific types of plagiarism have been also outlined; they are to be performed via uniform electronic data base designing on thesis themes confirmation by Academic boards of institutions of high education and scientific institutions. They are aimed at monitoring of present scientific and pedagogical researches tendencies and securing against their copying. The article indicates the importance of legal principles and efficacy of punishment mechanisms for academic dishonesty. The author also stresses on securing against unjust punishment via control of scientific violation reliability that consists of several stages, etc.

Keywords: academic virtue, academic dishonesty, plagiarism, types of plagiarism, correct citation, self-plagiarism.

\section{ВСТУП}

Постановка проблеми. Не зважаючи на апріорний характер поняття «академічна доброчесність», тобто логічність дотримання основних чеснот у сфері науково-педагогічних досліджень, біблійська заповідь «не вкради», повсякчас порушується у наукових колах. Проблеми академічної доброчесності нині актуальні у різних галузях, наприклад: управління, медицини, педагогіки, психології та ін.

Аналіз наукових досліджень і публікацій. Проблему вияву плагіату у ґрунтовному дослідженні сфери соціальних комунікацій названо складним контроверсійним явищем, для визначення якого сформульовано відповідні критерії та запропоновано авторську модель боротьби з указаним явищем (Рижко О., 2017, с. 3). Науковцями схарактеризовано форми, види та причини вдавання авторів до академічної недоброчесності; визначено особливості організації студентської науково-дослідницької діяльності на засадах академічної доброчесності (Варава І. М., 2019, с. 22); висвітлено аспекти неправомірного використання інтелектуальної власності у галузі науки; описано системи контролю перевірки наукових текстів щодо їх автентичності (Гайтан О. М., Горошко А. І., 2018, с. 22); опрацьовано методи протидії чинним автосистемам визначення плагіату наукових робіт (Артамонов Є. Б., 2012, с. 12) тощо.

Сучасними авторами запропоновано введення до навчальних курсів закладів вищої освіти спеціальних навчальних дисциплін (Варава І. М., 2019; Слободянюк О. М., 2018), роз'яснення цілей академічної сумлінності, причини та види порушень, способи боротьби з ними (Бардонова Л. А., Бєлих Є. Г., Бивальцев В. А., Калінін А. А., Степанов І. А., 2017) з метою убезпечення студентів та молодих науковців від порушення правил академічної доброчесності. Принагідно зазначимо, що нині у кожному закладі вищої освіти прийнято та реалізуються основи Положення про академічну доброчесність здобувачів освіти та наукових, науково-педагогічних працівників.

\section{МЕТА І ЗАВДАННЯ ДОСЛІДЖЕННЯ}

Мета дослідження - на основі аналізу наукових джерел та емпіричного матеріалу з'ясувати сучасну сутність поняття «академічна доброчесність / недоброчесність» та схарактеризувати дискусійні питання кола досліджуваної проблеми.

\section{МЕТОДИ ДОСЛІДЖЕННЯ}

Для досягнення мети статті використано такі методи дослідження: аналіз, синтез, узагальнення, порівняння та інтерпретація наукових джерел й емпіричного матеріалу.

\section{РЕЗУЛЬТАТИ ДОСЛІДЖЕННЯ}

Значущість формування у молоді та науково-педагогічної спільноти академічної доброчесності не має одновекторного вираження, адже вона є інструментом забезпечення якості освіти, формуючи у студентів та науковців добровільну, свідому зацікавленість у ненавмисному плагіаті, з метою чого мають систематично удосконалюватися доступні програми перевірки робіт на наявність плагіату та інших форм недотримання академічної доброчесності (Сацик В., 2017, с. 5); впливаючи на створення громадян нового типу, запобігаючи інтелектуально-творчому занепаду та низькій якості навчання (Слободянюк О. М., 2018, с. 138); визначаючи престижність закладу вищої освіти, хоча ще донедавна на цю проблему не звертали належної уваги, а то й приховували чи замовчували її (Слободянюк О. М., 2018 , с. 4). Академічна недоброчесність, як антонім відповідної доброчесності, постає як чинник девальвації освіти 
та науки, як приклад нівелювання морально-етичних норм суспільства (Рижко О. М., 2017, с. 6), насамперед, через брак культурного складника - регулятора норм контролю та вияву актів наукової недоброчесності (Слободянюк О. М., 2018, с. 139). Дослідники (Бруй О., 2016, с. 5; Вергун А. Р., Савенкова Л. В., Чуканова С. О., 2016, с. 44; Сацик В., 2017; Слободянюк О. М., 2018) одностайні в тому, що науковому колу нашої країни поки що притаманне часте, негативне, катастрофічне явище плагіату. Досі тенденція академічної доброчесності сприймається почасти у нашій країні, як міфічна концепція, «модна» наукова тема, що не дозволяє «скоригувати політику забезпечення якості вищої освіти», закласти «фундамент внутрішньої гармонії людини», виховуючи інтелектуальну гідність, толерантність до різноманіття думок (Сацик В., 2017).

Виокремлюють різні види плагіату: реплікація, републікація, фальсифікація, мозаїчний плагіат, дослівний плагіат, поєднання власного та запозиченого тексту без цитування, неадекватне перефразування, копіювання наукової роботи іншого автора, згадування наукових джерел без посилань на автора, рерайт тощо (Бруй О., 2016, с. 4). У цьому значенні реплікація - подання науковцем однієї і тієї ж роботи декілька разів 3 метою підняття свого академічного рейтингу; рерайт - «переказ» чужих думок своїми словами, але зі збереженням сутності інформації (Вергун А. Р., Савенкова Л. В., Чуканова С. О., 2016, с. 8). Також виокремлюють такі види плагіату, як: «компіляція» (спеціальне компонування одного наукового тексту з декількох чужих) та «парафраза» - вид переказу чужого тексту своїми словами, але зі спеціальною заміною слів та знаків (Вергун А. Р., Савенкова Л. В., Чуканова С. О., 2016, с. 8). Порушенням авторських прав К. Шахбазян вважає такі ключові вияви: 1) брак посилання на першоджерело цитати у списку використаної наукової літератури; 2) брак посилання у випадку використання графічних матеріалів (Шахбазян К. С., 2017, с. 54); 3) порушення правил цитування шляхом привласнення авторської думки (Шахбазян К. C., 2017, с. 56).

Системно досліджуючи проблему вдавання до плагіату, характеризують це поняття як багатоаспектне, визначаючи його сутність за галузями освіти, науки та життя, узагальнення чого ми подаємо у таблиці 1.

Таблиця 1

Різноаспектність поняття «плагіат» з точки зору певної галузі (за Рижко О. М., 2017, с. 2)

\begin{tabular}{|c|l|l|}
\hline № & Галузь, у якій виявляють плагіат & \multicolumn{1}{c|}{ Сутність плагіату } \\
\hline 1. & Аксіологія & Деструктивна трансформація парадигм та цінностей. \\
\hline 2. & Соціальні комунікації & $\begin{array}{l}\text { Перверсія, коригована зміщенням пріоритетів у поданні } \\
\text { інформації, попри якість, у швидкості. }\end{array}$ \\
\hline 3. & Етика & $\begin{array}{l}\text { Порушення етичного кодексу певної професії на різних } \\
\text { рівнях. }\end{array}$ \\
\hline 4. & Література & $\begin{array}{l}\text { Від ознаки постмодернізму (ознака розвитку } \\
\text { літератури) до інтелектуальної крадіжки (присвоєння } \\
\text { чужого авторства літературного твору). }\end{array}$ \\
\hline 5. & Юриспруденція & \begin{tabular}{l} 
Порушення авторського права. \\
\hline
\end{tabular} \\
\hline
\end{tabular}

Як видно з таблиці 1, ключовим, спільним загалом для галузей вияву плагіату є поняття «порушення» у прямому чи синонімічному значенні (деструкція, перверсія) викладу наукового матеріалу. Зважаючи на вказану вище різноаспектність поняття «плагіат», пропонують його уточнення шляхом уведення терміну «плагіат ідей» (Рижко О. М., 2017, с. 4), а самоплагіат називає «авторським дублюванням наукових результатів» (Рижко О. М., 2017, с. 3).

Водночас поняття «академічна доброчесність» виходить за рамки традиційного поняття «плагіат». Це складне, багатофункціональне явище, порушення якого охоплює: обман (свідоме надання неправдивої наукової чи діяльнісної інформації); фабрикацію (фальсифікацію результатів дослідження, посилань та будь-яких інших даних); списування (використання додаткових джерел інформації у процесі оцінювання якості знань чи діяльності); академічний плагіат, у тому числі - самоплагіат; хабарництво - надання / отримання матеріальної / нематеріальної оплати учаснику освітнього / наукового процесу за приховування / фальсифікацію результатів цього процесу (Радейко Р., 2020).

Важливо зрозуміти сутність та інтерпретацію усіх понять, враховуючи аналізоване поняття «плагіат», дотичних до проблеми академічної доброчесності: авторська / загальновідома інформація, цитата, цитування, самоцитування, самоплагіат тощо.

В окремих дослідженнях запропоновано класифікацію плагіату за такими критеріями: об'єкт присвоєння; мета використання; джерело присвоєння; характер подій; суб'єкт-суб'єктні відносини; технологія використання; мова подання; ступінь прозорості; ступінь оригінальності джерела плагіату; категорія результатів інтелектуальної власності; тип реальності; мотив; сфера; специфіка вияву (Рижко О. М., 2017, с. 6). Також розрізнено певні види плагіату шляхом зарахування чи незарахування до цієї категорії, наприклад: 1) рерайту - через потрактування в якості або твору, або тексту, оскільки це - «продукування вторинних текстів», трансформування даного, а не створення нового; 2) копіпасту, активно використовуваного у соціальних комунікаціях; 3) парафрази - переказу чужих думок своїми словами тощо. О. Рижко наголошує, що зарахування чи незарахування твору до плагіату 
залежить від таких чотирьох критеріїв: 1) посилання на першоджерело; 2) ступеня творчого опрацювання матеріалу; 3) нової якості створеного тексту; 4) наукової новизни новоствореного продукту (Рижко О. М., 2017, с. 4-5).

Як показали результати аналізу вказаних вище наукових джерел та емпіричного матеріалу, найбільше помилок роблять здобувачі освіти та молоді науковці у процесі цитування, що й призводить до порушення академічної доброчесності.

Типовими помилками при цитуванні називають:

1. «Порушення правил вторинного цитування»: використання інформації, яку знайдено не у першоджерелі, а у цитуванні іншим автором.

2. Дослівний переказ тексту та черги з цитування.

3. Неправильний переклад іноземних авторів тощо (Шахбазян К. С., 2017, с. 55).

Як показують результати проведеного нами дослідження, до плагіату найменше вдаються ті студенти, магістранти, аспіранти, у котрих ще на етапі перших років студентства, у рамках вивчення навчальної дисципліни «Основи наукових досліджень» та написання першої курсової роботи були дуже вимогливі викладачі, які не допускали халатного ставлення до виконання науково-навчальних завдань.

Цілком погоджуючись з виокремленими видами плагіату, уточнюємо їх назву (прямий плагіат, набір цитат, цитування за цитуванням, неправильний переклад), вказуючи практичні приклади та шляхи усунення таких помилок:

1. Дослівне копіювання тексту - прямий плагіат. Так, приміром, одному зі студентів освітнього рівня «бакалавр» було дано завдання використати у своїй роботі статтю одного із провідних дослідників. Студент дослівно виконав завдання, не вбачаючи у цьому порушення: скопіював статтю без змін і вставив до своєї курсової роботи усі 10 сторінок чужої праці. Щоправда, до списку своїх використаних джерел додав список джерел, використаних у статті, і вже у квадратних дужках у тексті змінив порядкові номери відповідно до новостворених. Шляхи усунення такого виду плагіату: цілеспрямоване навчання здобувачів освіти правилам правомірного цитування, ознайомлення із сутністю академічної доброчесності.

2. Набір цитат шляхом використання технології «копіювати - вставити». Досить часто до цього вдаються студенти, та й, почасти, молоді науковці, переконуючи, що для створення такого набору цитат опрацювали значну кількість наукових робіт та виявили логіку у порядку причинно-наслідкового чи підрядного зв'язку між вибраними цитатами. Йдеться, передусім, про недоліки або брак формування наукового мислення та першочергового розуміння сутності понять «науковий текст» та «наукова обробка інформації» шляхом застосування методів аналізу, синтезу, порівняння, узагальнення, уточнення тощо. Для подолання такого виду плагіату необхідне не лише роз'яснення певного виду порушення академічної доброчесності, а й практичне вправляння на заняття з «Основ наукових досліджень» та на інших заняттях у застосуванні вказаних вище методів опрацювання наукових джерел, у формулюванні висновків 3 окремо опрацьованих цитат тощо.

3. Цитування за цитуванням або вдавання до «наукових пліток». По-перше, не можемо бути впевненими у тому, що автор, який вже використав обрану нами цитату, зробив це правильно, без помилок. По-друге, не можемо використовувати наукове джерело, яке нами не опрацьовано. Водночас зовсім донедавна (років 10 тому) у наукових джерелах досить часто можна було зустріти такий вид посилання, наприклад: [цитата за 34]. 3 точки зору емоційності навчання, щоб пояснити студентам / магістрантам / аспірантам на лекції антилогіку такого посилання, ми вдаємося до народного порівняння: «Сказав Омелько, що Параска сказала», правомірність яких ніхто не гарантує. Отже, необхідно привчати молодих дослідників до пошуку першоджерела та опрацювання літератури, посилання на яку знайшли у результаті аналізу певної наукової праці.

4. Неправильний переклад даних та праць іноземних авторів шляхом інтернет-перекладу або самостійного словникового перекладу. Особливо багато помилок шляхом потрійного перекладу з різних мов, що часто призводить навіть до кумедного плагіату. Наприклад, подане англійською мовою у статті прізвище науковця Odet, було висвітлено на сайті журналу також російською мовою - Одет. Проте вже українською мовою отримали прізвище «Одягнутий». Магістрант не звернув уваги на результат перекладу. Щодо перекладу цитат - аналогічні приклади. Таким чином, необхідно привчати молодих науковців до вивчення іноземної мови, уважного перечитування результатів перекладу та вдавання до послуг професійних перекладачів.

Дискусійними, на наш погляд, залишаються питання щодо визначення рівня дотримання академічної доброчесності, запропоновані (Шахбазян К. С., 2017, с. 56) залежно від мети використання твору - комерційності / некомерційності, сутності твору, захищеного авторським правом тощо. Означена дискусійність спричинена неоднозначністю присвоєння авторського права на твір, передусім, у сфері гуманітарних наук.

У результаті аналізу наукових джерел нами узагальнено пропозиції дослідників щодо шляхів усунення академічної недоброчесності (таблиця 2).

Підтримуючи вказані вище пропозиції, ґрунтуючись на результатах власного практичного досвіду щодо досліджуваної проблеми, пропонуємо навчати здобувачів освіти основам наукової етики, технологіям виконання наукових робіт, розпочинаючи із першого курсу освітнього рівня «бакалавр».

Проведені нами анкетування та опитування, застосування в обговоренні методу «мозковий штурм» також дозволили визначити такі психологічні причини порушення академічної доброчесності як здобувачів освіти, так і досвідчених науковців: заздрість стосовно наукових досягнень інших колег; страх перед невиконанням наукового завдання; комплекси неповноцінності, невпевненості та зневіри у своїх силах; лінь та, як наслідок, використання легких шляхів виконання роботи, піддаючись «спокусі» безлічі пропозицій виконання роботи способом «скачати»; соціальна «мода» на поведінку певних людей за правилом: «Роби так, як усі! Не йди складним шляхом!» тощо. 
Пропозиції дослідників щодо шляхів усунення академічної недоброчесності

\begin{tabular}{|c|c|c|}
\hline № & Шляхи усунення академічної недоброчесності & Автор ідеї \\
\hline 1 & $\begin{array}{l}\text { Своєчасне надання завдання; відслідковування поетапного } \\
\text { виконання здобувачем наукового проєкту, якщо причиною } \\
\text { плагіату є брак часу у здобувачів освіти, зокрема у ситуації } \\
\text { подання роботи згідно із чітко встановленими термінами. }\end{array}$ & Артамонов Є. Б., 2012, с. 13. \\
\hline 2 & $\begin{array}{l}\text { Уведення до навчальних курсів університетів навчальної } \\
\text { дисципліни «Академічне письмо» («Наукове письмо»). }\end{array}$ & Варава І. М., 2019, с. 22. \\
\hline 3 & $\begin{array}{l}\text { Уведення до навчальних курсів університетів навчальної } \\
\text { дисципліни «Етичне прийняття рішень та етика в освітньому } \\
\text { середовищі університету»; розроблення та впровадження } \\
\text { «Положення про академічну доброчесність». }\end{array}$ & Слободянюк О. М., 2018, с. 138-139. \\
\hline 4 & $\begin{array}{l}\text { Подальша розробка універсальних навчальних модулів, } \\
\text { у яких кожному вченому-початківцю будуть роз'яснені } \\
\text { цілі академічної сумлінності; найчастіші причини, котрі } \\
\text { спричинюють ї̈ порушення; описано види інших порушень, } \\
\text { можливі наслідки та способи боротьби з ними. }\end{array}$ & $\begin{array}{l}\text { Бардонова Л. А., Бєлих Є. Г., } \\
\text { Бивальцев В. А., Калінін А. А., } \\
\text { Степанов І. А., 2017, с. } 301 .\end{array}$ \\
\hline
\end{tabular}

Зазначене підтверджує необхідність цілеспрямованого навчання здобувачів освіти, розпочинаючи з бакалаврату, етиці та методології наукової діяльності. Хоча, як зазначають результати критичного аналізу боротьби у нашій країні з академічною недоброчесністю, цей процес водночас набув бюрократичного характеру: ілюзія значущості наукометричних показників, халатне ставлення членів редакційної колегії наукових журналів до виконання своїх обов'язків або ж їх невиконання солідними членами редколегії, яких штучно уведено до такого переліку через поважні наукові досягнення (Попович О. С., 2020).

На наше переконання, боротьба 3 академічною недоброчесністю повинна здійснюватися цілеспрямовано, системно та узгоджено у державному й міжнародному масштабах, не лише у форматі поінформованості щодо відповідальності за порушення правил антиплагіату та умінь правильного цитування, а 3 метою формування спеціальних професійних і загальнокультурних цінностей як у студентів, так і у науково-педагогічних працівників. Важливим, на наш погляд, є не лише об'єктивне виявлення академічної недоброчесності, а й нормативно-правове забезпечення та дієвість механізмів покарання за вияв цього явища (позбавлення наукових ступенів / звань чи нагород, відрахування з навчання, звільнення з роботи тощо). Однак 3 метою убезпечення від несправедливого покарання має бути передбачена кількаступенева перевірка вірогідності порушення академічної доброчесності, а не сліпа довіра комп'ютерній програмі, яка також може давати збій.

Вияв плагіату може мати й інші суперечливі аспекти. Наприклад, якщо «крадіжка» авторства у вигляді ідеї, концепції, прямого фрагменту тощо відбулася у вигляді прямої «крадіжки», тобто оприлюднення чужих ідей до моменту їх публікації самим автором. На жаль, історія розвитку будь-якої галузі людської діяльності має такі приклади, відстоювання справедливості у яких судовим шляхом не завжди закінчувалося, як і будь-який юридичний факт, перемогою для постраждалої сторони - реального автора. У цьому випадку, на наш погляд, недосвідчених авторів науково-творчих проєктів необхідно навчати певній «дослідницько-авторській безпеці», що передбачає: контроль за розташуванням матеріалу (встановлення паролю та інших форм дотримання безпеки на персональному комп'ютері; зберігання результатів досягнень у надійному місці тощо) та розголошенням власне ідеї (оприлюднення результатів роботи в усній формі лише після їх публікації); своєчасне затвердження теми та очікуваних результатів дослідження за відповідними процедурами (на засіданнях учених рад тощо); захист авторських прав шляхом відповідної їх реєстрації тощо.

Попри загальну активізацію інтересу до проблем академічної доброчесності маємо суперечливі позиції щодо окремих видів плагіату, насамперед, самоплагіату. Тобто, якщо нині перевірити захищені дисертації до 2014 р., то виявиться масове явище самоплагіату, зокрема, у тих авторів, які видавали монографії та статті за чинним на той час правилом: «зміст статей, монографії відповідає змісту дисертації». Однак юридично правомірно буде вважати порушення правил самоцитування та вдавання до самоплагіату саме з моменту набуття чинності відповідних нормативно-правових документів (Закон України «Про вищу освіту», 2014; Положення про Національний репозитарій академічних текстів, 2017). Хоча, на нашу думку (про що досі тривають наукові дискусії: аргументують позиції «за» та «проти») нині є дещо нелогічним оприлюднення дисертаційних робіт у форматі наукових публікацій, нетотожних самій роботі, але обов'язково, висвітлюючи кожну позицію підрозділу остаточного варіанту дисертації: у висновках до кожного розділу дисертаційної роботи мають бути чітко вказаними посилання на публікації автора, де оприлюднено матеріали цього розділу. Зазначене, по-перше, як вказано нами, має дискусійний характер: тобто, щоб не було самоплагіату, а зміст статті висвітлював зміст певного підрозділу дисертації, необхідно кардинально перефразувати авторські тлумачення ключових понять дослідження. Як результат, маємо названі нами 
«переформульовані статті», а рецензенти, експерти, аналізуючи роботу, констатують неузгодження тлумачень та інших наукових позицій у публікаціях здобувача, в яких опубліковано основні наукові результати дисертації, однак приймають зазначене, як належне, адже головний показник - брак плагіату. Можливо, для вирішення вказаної проблеми, доречно формулювати до вимог написання дисертаційних робіт публікувати не основні, а одразу категорію наукових публікацій, що додатково відображають наукові результати дисертації, адже основні - у тексті дисертації та тезово - у апробаційних джерелах. По-друге, вказане спонукає науковців, з причини вимоги, так би мовити, «написати про те саме іншими словами», до пошуків нових форм та методів плагіату - академічної недоброчесності. Так, найпопулярнішими методами цього контексту стало написання фахових публікацій шляхом перекладу через інтернет-перекладача зарубіжних наукових публікацій (з англійської, російської та інших мов). У кінцевому варіанті системи антиплагіату не можуть встановити та ідентифікувати першоджерело наукової інформації і, як результат, не констатують плагіату наукової роботи.

\section{ВИСНОВКИ ТА ПЕРСПЕКТИВИ ПОДАЛЬШИХ ДОСЛІДЖЕНЬ}

Таким чином, дискусійними питаннями контексту проблеми академічної доброчесності є: характеристика критеріїв визначення окремих видів академічної недоброчесності, зокрема щодо самоплагіату, наприклад, у вигляді несвідомого порушення шляхом оприлюднення результатів дисертаційних робіт у перефразованих статтях тощо, адже досі неунормовано змістову залежність тексту дисертації та супровідних наукових публікацій автора. Щоб уникнути окремих видів плагіату та зайве не дискутувати довкола означеного питання, доречно: створити єдину електронну базу даних щодо затвердження ученими радами закладів вищої освіти та наукових інститутів тем наукових досліджень (електронна реєстрація) з метою відстеження тенденцій сучасних науково-педагогічних досліджень та убезпечення їх дублювання; оновити нормативно-правове забезпечення та дієвість механізмів покарання за вияв академічної недоброчесності; визначити методи убезпечення від несправедливого покарання за академічну недоброчесність шляхом кількаступеневої перевірки вірогідності наукового порушення тощо.

Подальшого дослідження потребує питання характеристики змісту навчальних дисциплін контексту формування академічної доброчесності у здобувачів освіти та молодих науковців.

Автори статті виносять подяку за технічну допомогу у процесі її написання членам наукового гуртка "Школа організатора освітнього простору" УдпУ імені Павла Тичини: Будегай Вікторії, Пишній Наталії.

\section{СПИСОК ВИКОРИСТАНИХ ДЖЕРЕЛ}

Артамонов, Є. Б. (2012). Аналіз методів протидії автоматичним системам визначення плагіату в електронних документах. Проблеми інформатизації та управління, 4 (40), 12-18.

Бруй, О. (2016). Передмова. Міжнародні правила цитування та посилання в наукових роботах: методичні рекомендації / автори-укладачі: О. Боженко, Ю. Корян, М. Федорець; Українська бібліотечна асоціація. Київ: УБА, 4-8.

Бывальцев, В. А., Степанов, И. А., Белых, Е. Г., Калинин, А. А., Бардонова, Л. А. (2017). Плагиат и академическая добросовестность в науке. Вестник РАМН, 72/4, 299-304.

Варавай, І. М. (2019). Проблема академічної доброчесності у сучасному суспільно-освітньому середовищі. Науковий часопис НПу імені М. П. Драгоманова. Серія 5: Педагогічні науки: реалії та перспективи, Випуск. 66, 22-26.

Гайтан, О. М., Горошко, А. І. (2018). Порівняльний аналіз систем автоматичної перевірки оригінальності текстів. Вчені записки ТНУ імені В. І. Вернадського. Серія: технічні науки. Том 29 (68), Ч. 1, № 5, 98-104.

Кулинкович, Т. О. (2010). Основы научного цитирования: метод. пособие для студентов и магистрантов, обучающихся по спец. 1-23 0104 «Психология». Минск: БГУ, 58.

Попович, О. С. (2020) Наукометричне невігластво (щодо манії бюрократій запровадити цифрове оцінювання науки). URL: https://unsci.com/ru/ 2020/02/06/naukometrichne-neviglastvo-shhodo-maniï-byurokratij-zaprovaditi -czifrove-oczinyuvannya-nauki/?fbclid=I wAR1YpJPLrOdvej1b2a7C_DwPxORzWZpwaR1g

Про вищу освіту: Закон України від 01.07.2014 р. № 1556-XVII (2018) URL: http://zakon2.rada.gov.ua/laws/show/1556-18

Програмне забезпечення для перевірки наукових текстів на плагіат: інформаційний огляд / автори-укладачі: А. Р. Вергун, Л. В. Савенкова, С. О. Чуканова; редколегія: В. С. Пашкова, О. В. Воскобойнікова-Гузєва, Я. Є. Сошинська (2016). Українська бібліотечна асоціація. Київ: УБА, 36.

Про затвердження Положення про Національний репозитарій академічних текстів: Постанова Кабінету Міністрів України від 19.07.2017 № 541. (2017) Офіційний веб-сайт Верховної Ради України. URL: http://zakon3.rada.gov.ua/laws/show/541-2017-\%D0\%BF

Радейко, Р. (2020) Що таке академічна доброчесність? URL: http://aphd.ua/ shcho-take-akademichna-dobrochesnist/

Рижко, О. М. (2017). Плагіат у соціально-комунікаційному вимірі початку XXI столітя: природа явища та історія боротьби: дис. ... д-ра наук із соціальних комунікацій: 27.00.01. / Інститут журналістики КНУ імені Тараса Шевченка, Київ, 438.

Сацик, В. (2017). Академічна доброчесність: міфічна концепція чи дієвий інструмент забезпечення якості вищої освіти? URL: http:// library.uipa.edu.ua/poslygy/naukovtsiam-fakhivtsiam/naukovtsiam/ akademichna-dobrochesnist.html

Слободянюк, О. М. (2018). Роль науково-педагогічного колективу у формуванні культури академічної доброчесності студентів. Вісник Вінницького політехнічного інституту, №. 6,134-139.

Шахбазян, К. С. (2017). Застосування в наукових публікаціях цитат із опублікованих творів, права на які належать іншим авторам. Наука України у світовому інформаційному просторі. Київ: Академперіодика, Вип. 14, 51-58.

\section{REFERENCES}

Artamonov, E. B. (2012). Analiz metodiv protydiyi avtomatychnym systemam vyznachennya plahiatu $v$ elektronnykh dokumentakh. Problemy informatyzatsiyi ta upravlinnya, 4 (40), 12-18. 
Bruy, O. (2016). Peredmova. Mizhnarodni pravyla tsytuvannya ta posylannya v naukovykh robotakh: metodychni rekomendatsiyi / avtory-ukladachi: O. Bozhenko, Y. Koryan, M. Fedorets'; redkolehiya: V. S. Pashkova, O. V. Voskoboynikova-Huzyeva, Y. E. Soshyns'ka, O. M. Bruy; Ukrayins'ka bibliotechna asotsiatsiya. Kyyiv: UBA, 4-8.

Byval'tsev, V. A., Stepanov I. A., Belykh Y. G., Kalinin A. A., Bardonova L. A. (2017). Plagiat i akademicheskaya dobrosovestnost' v nauke. Vestnik RAMN, 72/4, 299-304.

Varava, I. M. (2019). Problema akademichnoyi dobrochesnosti u suchasnomu suspil'no-osvitn'omu seredovyshchi. Naukovyy chasopys NPU imeni M. P. Drahomanova. Seriya 5: Pedahohichni nauky: realiyi ta perspektyvy. Vypusk, 66, 22-26.

Haytan, O. M., Horoshko, A. I. (2018). Porivnyal'nyy analiz system avtomatychnoyi perevirky oryhinal'nosti tekstiv. Vcheni zapysky TNU imeni V. I. Vernads'koho. Seriya: tekhnichni nauky, Tom 29 (68), CH. 1, № 5,98-104.

Kulinkovich, T. O. (2010). Osnovy nauchnogo tsitirovaniya: metod. posobiye dlya studentov i magistrantov obuchayushchikhsya po spets. 1-23 01 04 «Psikhologiya». Minsk: BGU, 58.

Popovych, O. S. (2020) Naukometrychne nevihlastvo (shchodo maniyi byurokratiy zaprovadyty tsyfrove otsinyuvannya nauky). Retrieved from: https://un-sci.com/ru/2020/02/06/naukometrichne-neviglastvo-shhodo-maniyi-byurokratij-zaprovaditi-czifrove-oczinyuvannya-nauki/?fbclid =IWAR1YpJPLrOdvej1b2a7C_DwPxORzWZpwaR1g

Pro vyshchu osvitu: Zakon Ukrainy vid 01.07.2014 p. № 1556-XVII. (2014). Retrieved from: http://zakon2.rada.gov.ua/laws/show/1556-18

Prohramne zabezpechennya dlya perevirky naukovykh tekstiv na plahiat: informatsiynyy ohlyad / avtory-ukladachi: A. R. Verhun, L. V. Savenkova, S. O. Chukanova; redkolehiya: V. S. Pashkova, O. V. Voskoboynikova-Huzyeva, YA. YE. (2016). Soshyns'ka; Ukrayins'ka bibliotechna asotsiatsiya. Kyyiv: UBA, 36.

Pro zatverdzhennya Polozhennya pro Natsional'nyy repozytariy akademichnykh tekstiv: Postanova Kabinetu Ministriv Ukrayiny vid 19.07.2017 № 541. Ofitsiynyy veb-sayt Verkhovnoyi Rady Ukrayiny. (2017). Retrieved from: http://zakon3.rada.gov.ua/laws/show/541-2017-\%D0\%BF

Radeyko, R. (2020) Shcho take akademichna dobrochesnist'? Retrieved from: http://aphd.ua/shcho-take-akademichna-dobrochesnist

Ryzhko, O. M. (2017). Plahiat u sotsial'nokomunikatsiynomu vymiri pochatku KHKHI stolittya: pryroda yavyshcha ta istoriya borot'by: dys. ... d-ra nauk iz sotsial'nykh komunikatsiy: 27.00.01. / Instytut zhurnalistyky KNU imeni Tarasa Shevchenka, Kyyiv, 438.

Satsyk, V. (2017) Akademichna dobrochesnist': mifichna kontseptsiya chy diyevyy instrument zabezpechennya yakosti vyshchoyi osvity? Retrieved from: http://library.uipa.edu.ua/poslygy/naukovtsiam-fakhivtsiam/naukovtsiam/ akademichna-dobrochesnist.html

Slobodyanyuk, O. M. (2018). Rol' naukovo-pedahohichnoho kolektyvu u formuvanni kul'tury akademichnoyi dobrochesnosti studentiv. Visnyk Vinnyts'koho politekhnichnoho instytutu, №. 6, 134-139.

Shakhbazyan, K. S. (2017). Zastosuvannya v naukovykh publikatsiyakh tsytat iz opublikovanykh tvoriv, prava na yaki nalezhat' inshym avtoram. Nauka Ukrayiny u svitovomu informatsiynomu prostori. Kyyiv: Akademperiodyka, Vyp. 14, 51-58.

Статтю подано до редколегії 11.03 .2020 p.

Рекомендовано до друку 01.04.2020 p.

